\title{
Animal and human health: tackling uncertainty through participatory modelling and simulation
}

\author{
Raphaël DUBOZ - Aurélie BINOT
}

Zoonoses - infectious diseases communicable between animals and humans -, drug resistance and environmental pollution are now causing serious health problems worldwide. These problems are closely tied to global environmental and socio-economic changes and to the transformation of production systems at the territorial level. In this context, health management is becoming a complex issue: it needs to be addressed in close collaboration with the public veterinary health, agriculture and environment

$P$ ublic health practitioners agree today on the importance of jointly addressing the medical, social and environmental dimensions of infectious and parasitic diseases, especially zoonoses - diseases communicable between animals and humans. This approach incorporates knowledge from public health, animal health, agriculture and the environmental sciences. It provides a better understanding of the determinants and risk factors associated with health, with the goal of proposing management models to suit every context, whether local or regional.

This integrated approach to health - which is related to the One Health and EcoHealth approaches - nevertheless requires a new culture of collaboration between the actors concerned: it calls for interdisciplinarity from the scientific community and intersectorality from the institutional and professional communities.

Integrated health management: a complex issue, a growing uncertainty and new actors

The medical aspects of the management of health problems are crucial in public health, especially research to develop vaccines and drugs, research on risk factors (epidemiology), sectors. New uncertainties are emerging, and nonconventional actors are entering the scene alongside the decision-makers traditionally responsible for public health. The participatory modelling and simulation approach incorporates the diverse knowledge of all of these actors. It reveals uncertainties and teaches participants how to manage them, to make decisions and to share responsibility. It constitutes a practical solution to ensure health issues are better integrated into territorial planning policies.

and the creation of efficient, economically viable health care systems.

However, other aspects must also be taken into account for the management of diseases such as zoonoses, since their emergence and transmission are highly dependent on environmental management or the organisation of livestock sectors. One example is the social aspect: how do the people involved interact; how are they structured into networks and chains (consumers, intermediaries, etc.); how do they exchange information; and how do they make decisions? Another example is knowledge about agricultural sectors, which enables better understanding and management of zoonoses and animal diseases: unsafe farming or livestock production practices, the markets on which animal products are sold, and economic and social pressures that have an impact on biosecurity. Territorial governance is another aspect required in the organisation of health management: this implies clearly identifying the health status of humans and animals, establishing treatment requirements, and coordinating health policies with territorial planning and environmental management policies - especially on waste and water management.

This integrated approach to health is structured around three areas: 
> incorporating knowledge and data from social sciences, agronomy and environmental sciences;

> extending the panel of legitimate actors (doctors, veterinarians, public health practitioners] to include new institutional and social actors: government officers from the environment sector (forestry, wildlife, water management), agriculture or rural development as well as categories of social actors such as livestock producers and farmers, representatives of local authorities (village heads, customary leaders, etc.), animal product middlemen and dealers, and religious authorities. To add a further layer of complexity, these actors operate on different scales of action and different administrative levels:

$>$ creating new methods and tools to enable all of these actors to understand health issues at the territorial level with the territory used here in the sense of a socially and politically constructed space and the setting for interactions between actors.

Implementing this kind of approach makes it possible to consider new risk factors, for which knowledge is still partial, especially regarding the health impacts of global changes. Against a backdrop of rapid agricultural intensification, deforestation or urbanisation, how, for example, can economic and social practices be connected to the emergence of antimicrobial resistance, a major public health problem today, which is also linked to animal production sectors? Global changes increase and diversify sources of soil and water contamination, and produce new interfaces for contacts between humans, animals and their pathogens. The environment is constantly evolving, and accompanying this ongoing change through adaptive and participatory methods is a key innovation for decision support.

\section{Support for decision-making in public health at the territorial level}

For public health practitioners, acknowledging this complexity and taking it into account in the management of health risks increases the perception of uncertainties. This makes decision-making complicated given the large number of parameters and the impossibility of controlling them. The more complex the health issue, the more the actors concerned must learn to "live with" this uncertainty.

This is why we propose a participatory modelling and simulation approach to guide the consultation and decision-making process. This approach is largely inspired by companion modelling. The tools used lead the actors concerned by health issues in a given territory to cooperate, even though they may not necessarily know each other or work together. These tools enable them to join forces to build a shared representation of a complex situation and to simulate actions and their impacts in order to achieve consensus on the solutions.

This approach also provides the possibility of integrating health control and surveillance actions into the territorial context. It can thus accompany health management operations such as vaccination, drug distribution or surveillance of new clinical cases in human or animal populations.

\section{An approach inspired by companion modelling}

Companion modelling has been developed by the interdisciplinary scientific association ComMod, bringing together practitioners and researchers from different countries, institutions and disciplines. This approach is comprised of two participatory phases that can be repeated as many times as necessary: modelling then simulation.

The modelling phase - The facilitators of the approach ask the participants to identify the problems they wish to address together, then to describe the complexity of these issues. Progressively, they co-develop a representation (interaction diagrams, maps, etc.) of the dynamics and processes specific to their situation: for example, markets and supply chains at the territorial level, biological and physico-chemical processes (water cycle, disease transmission by biting insects, soil pollution by agriculture, etc.], institutional mechanisms, and power relations between social actors [politicians, community leaders, traders, landowners, etc.].

The participants thus develop a conceptual model that also incorporates scientific, socio-economic, political and ecological data that characterises their territory. This model enables them to explore the value of cooperation between the sectors concerned, for example, environment, agriculture and public health. It highlights the interactions between institutional actors (ministries of communication, defence or education] and civil society actors.

The simulation phase - The participants test scenarios and discuss their actions through participatory workshops, computerised simulations or role-playing games. These simulations are based on conceptual models jointly developed by the participants. The following are two examples of actions discussed further to a simulation: setting up a management body representative of the actors concerned (interministerial group, village grouping, local authorities, etc.) to tackle livestock waste at the watershed scale; creating and disseminating communication tools (cartoons for schoolchildren, role-playing games for villagers, radio programmes, etc.) to better prepare people at risk to control food-borne parasitic diseases.

When the participants co-develop simulations and explore scenarios, they bring to light missing stakeholders, new questions and knowledge gaps. They can then repeat the modelling phase, adding these elements, in order to

\section{A role-playing session with villagers in Kampot, Cambodia.}

(C) Photo CIRAD - EuropeAid ComAcross project

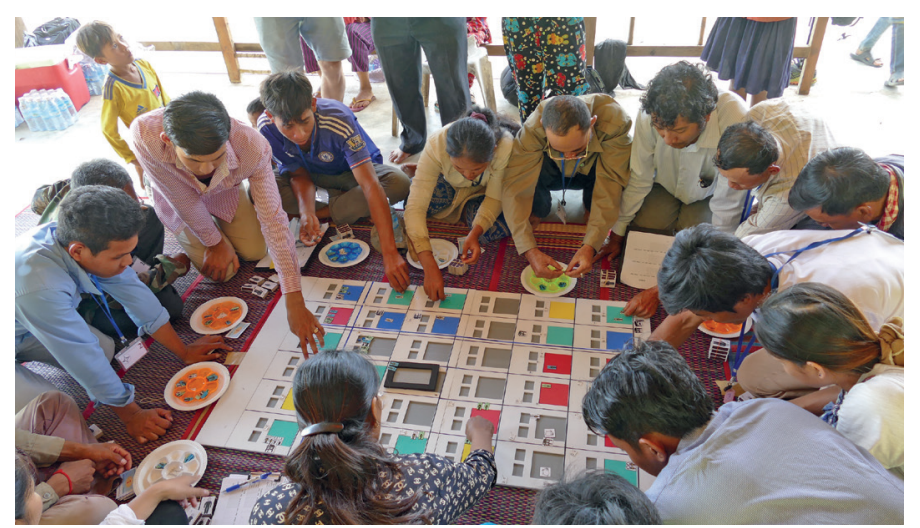


Participatory modelling and simulation, a learning process well suited to the management of complex health problems in Southeast Asia and Southern Africa

Participatory modelling and simulation, and companion modelling, are being successfully used by researchers from CIRAD and their partners in Southeast Asia and Southern Africa in the management of health problems and the emergence of zoonoses. Role-playing games are being developed in order to strengthen collaborations between actors involved in health management for humans, animals and ecosystems. These simulations help to ensure better management of health problems at the agriculture-environment interface, by fostering better communication about risks. Government officials, village leaders, farmers, scientists and forest rangers are thus learning to communicate more effectively and to coordinate their actions during participatory simulation workshops. They are working on virtual situations arising from real-life cases, such as the prevention of Japanese encephalitis in Cambodia or foot-and-mouth disease on the fringes of protected areas in Zimbabwe.

Examples of real situations addressed using companion modelling:

> watershed-scale management of waste from livestock farms and rice paddies, in Thailand;

$>$ herd management support for people living in a protected area, taking account of risks linked to nearby wildlife, in Zimbabwe;

$>$ communication and consultation on modes of transmission for human encephalitis and on risk factors and unsafe practices and behaviours, in order to improve knowledge about these diseases at the local level, in Cambodia. produce a more accurate model and collective decisions. By getting to know each other and sharing their arguments, the participants step outside of their usual framework and allow themselves to explore innovative solutions. Companion modelling enhances the capacity of a group to anticipate problems and manage risks.

Throughout this process, the facilitator researchers comply with the ComMod network's charter of ethics, which sets out the position of the researcher accompanying the decision-making process. In order to apply this approach to health problems, an appropriate ethical committee is also mobilised.

\section{Sharing decision-making and responsibility, accepting uncertainty: model support}

Co-developing a model is a collective thought experiment aimed at steering choices and implementing actions. The success of this participatory approach depends on the validation of a consensus among actors: first during the construction of the model, and then during the simulation sessions.

This model is not an objective representation of reality, since it is based on the knowledge and objectives deemed to be the most relevant at a given time by participants. Nor is it predictive. Moreover, it is generally impossible to validate the model by comparing the results of participatory simulations with field data. Its validation lies in the collective acknowledgement of its value through the learning and decisionmaking processes it fosters. Likewise, it only explores certain scenarios chosen by the participants. Here, the model serves to define health status indicators to assess the impact of decisions made using this model.

Consequently, it is essential to establish the limits of this approach. The participants agree on what is included in the system studied in relation to the problem posed, and on the simplifications required to produce the model. This discussion enables them to focus on what really matters and to assign priorities. The participants making decisions thereby gain a better understanding of the sources of uncertainty inherent in any modelling process.
Participatory modelling and simulation applied to health management also contribute to better management of the tensions caused by interdisciplinarity and intersectorality. Healthcare and environmental professionals, farmers, livestock producers and local decision-makers compare their knowledge and practices on equal terms. Their inclusion in the model creates a space in which no single actor holds all the knowledge or has the capacity to make decisions alone. Decisions are collectively developed and approved, and responsibility can thus be politically shared.

\section{Better integrating health into territorial planning policies}

The companion modelling approach has been widely explored for environmental governance and for the management of protected areas or rangelands, often in conflict situations in which actors have different views on territorial planning.

The participatory and collaborative approaches linked to this process are well-suited to complex health problems, as shown by the recent initiatives conducted by CIRAD and its partners in Asia and Africa (see box above).

We propose decision support and capacity building for territorial actors to enable them to manage public health within a broader framework, incorporating issues related to global changes and to their health impacts in connection with agriculture and the environment. This integration is a key challenge for research for development. The participatory modelling and simulation approach is a source of innovation to manage emerging health risks and to address the social concerns they raise. It opens up new possibilities for articulating health challenges and goals with those of sustainable development.

Finally, this companion modelling approach engages researchers socially and enables them to become actors in their own right. They work alongside territorial actors to incorporate health problems into development plans and local policy agendas. 
Perspective $\mathrm{n}^{\circ} 41$ is the result of research conducted by the authors and their colleagues and partners in the context of two of CIRAD's Platforms in Partnership for Research and Training:

- GREASE [Management of Epidemiological Emerging Risks in Southeast Asia, www.grease-network.org/];

- RP-PCP [Research Platform Production and Conservation in Partnership, Southern Africa, www.rp-pcp.org/].

This research has led to several publications, including:

Binot A., Duboz R., Promburom P., Phimpraphai W., Cappelle J., Lajaunie C., Goutard F.L., Pinyopummintr T., Figuié M., Roger F., 2015. A framework to promote collective action within the One Health community of practice: Using participatory modelling to enable interdisciplinary, cross-sectoral and multi-level integration. One Health 1: 44-48.

http://dx.doi.org/10.1016/j.onehlt.2015.09.001.

Collineau L., Duboz R., Paul M., Peyre M.I., Goutard F., Holl S., Roger F, 2013. Application of loop analysis for the qualitative assessment of surveillance and control in veterinary epidemiology. Emerging Themes in Epidemiology 10:7.

http://dx.doi.org/10.1186/1742-7622-10-7.

Duboz R., Müller J.P., 2013. Modélisation des socio-écosystèmes. Instrumenter le dialogue multidisciplinaire. In Varenne F., Silberstein M. [Eds] Epistémologie de la modélisation et de la simulation, p. 865-896. Éditions Matériologiques, Paris. ISBN 978-2-919694-37-2.

Duboz R., Soulié J.C., 2013. Modeling and simulation of living systems as systems of systems. In Zeigler B.P., Sarjoughian H.S. [Eds] Guide to Modeling and Simulation of Systems of Systems. Series Simulation Foundations, Methods and Applications, p. 281-305. Springer, London. ISBN 978-0-85729-865-2.

Goutard F.L., Binot A., Duboz R., Rasamoelina-Andriamanivo H., Pedrono M., Holl D., Peyre M.I., Cappelle J., Chevalier V., Figuié M., Molia S., Roger F.L., 2015. How to Reach the Poor? Surveillance in low-income countries, lessons from experiences in Cambodia and Madagascar. Preventive Veterinary Medicine 120[1]: 12-26. http://dx.doi.org/10.1016/j.prevetmed.2015.02.014.

Kassie D., Binot A., Peyre M., Delabouglise A., Hoa T.T.H., Roger F., 2017. Géographie de la santé : recourir aux constructions territoriales pour mieux gérer la santé humaine et animale. In Caron P., Valette E., Wassenaar T., Coppens d'Eeckenbrugge G., Papazian V. [Eds] Des territoires vivants pour transformer le monde. Editions Quae, Versailles. ISBN 978-2-7592-2654-2.

Perrotton A., De Garine-Wichatitsky M., Valls-Fox H., Le Page C., 2017. My cattle and your park: Co-designing a role-playing game with rural communities to promote multi-stakeholder dialogue at the edge of protected areas. Ecology and Society 22[1]: e35. https://doi.org/10.5751/ES-08962-220135.

\section{A few words about...}

Raphaël DUBOZ is a researcher in dynamic system modelling and simulation, specialising in the coupling and integration of heterogeneous models. $\mathrm{He}$ is a researcher at CIRAD, ASTRE Joint Research Unit (Animals, Health, Territories, Risks and Ecosystems, http://umr-astre.cirad.fr/]. He is currently developing a role-playing game and simulation models on the management of Japanese encephalitis and the risk of Nipah virus emergence at the Institut Pasteur du Cambodge (www.pasteur-kh.org), Cambodia. raphael.duboz@cirad.fr

Aurélie BINOT is an anthropologist and agronomist at CIRAD, ASTRE Joint Research Unit (Animals, Health, Territories, Risks and Ecosystems, http://umr-astre.cirad.fr/]. She is coordinator of a EuropeAid project for the implementation of interdisciplinary One Health actions in Southeast Asia, and a member of networks focusing on the collective management of emerging health risks at the human-animal-environment interface. aurelie.binot@cirad.fr

\section{A few links}

ComAcross (Companion Approach for cross-sectoral collaboration in health risk management in South East Asia], EuropeAid project coordinated by CIRAD, developing companion approaches.

www.onehealthsea.org/comacross

ComMod: The Companion Modelling approach. www.commod.org/en

Roger F., 2012. Control of zoonotic diseases in Africa and Asia. The contribution of research to One Health. CIRAD, Montpellier, Perspective 18. http://dx.doi.org/10.18167/agritrop/00024

United Nations. Sustainable Development Goals. www.un.org/sustainabledevelopment/

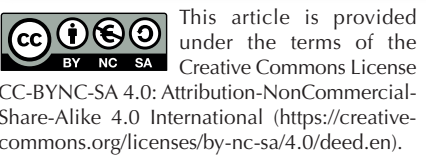

commons.org/licenses/by-nc-sa/4.0/deed.en).
To cite this document

Duboz R., Binot A., 2017. Animal and human health: tackling uncertainty through participatory modelling and simulation. CIRAD, Montpellier, Perspective 41.

http://dx.doi.org/10.18167/agritrop/00043
Publication Director: Michel Eddi, CIRAD President Managing Directo Editor: Patrick Caron, Office of the Director Genera in charge of Research and Strategy Coordination: Cécile Fovet-Rabot, Scientific and Technical Information Service AGRICULTURA R FOR DEVELOPMENT 42 , rue Scheffer 75116 Paris • FRANCE Translation: Anna Kiff

Graphic design: Laurence Laffont

Distribution: Christiane Jacquet, Communication Service Email: perspective@cirad.fr

www.cirad.fr/en/publications-resources/publishing/perspective-policy-brief perspactive ISSN-L 2275-9190 